\title{
ECENG GONDOK SEBAGAI BAHAN BAKU PAPAN PARTIKEL
}

\author{
Wahyu Nurramadhan, Irza Ahmad, Nira Nasution
}

\begin{abstract}
ABSTRAK
Penelitian ini bertujuan untuk mengetahui nilai dari sifat fisik kerapatan, kadar air, pengembangan tebal, dan sifat mekanik keteguhan lentur serta modulus elastisitas papan partikel dengan bahan baku eceng gondok dan perekat urea formaldehida (UF) serta hardener $\left(\mathrm{NH}_{4} \mathrm{CL}\right)$ sesuai dengan persyaratan SNI 03-2105-2006.

Dalam penelitian ini menggunakan metode eksperimen, populasi sebanyak 7 papan dengan ukuran $30 \times 30 \times 1 \mathrm{~cm}$, sedangkan sampel diambil sebanyak 10 buah dari setiap 1 papan, 1 sampel untuk kerapatan dan kadar air, 3 sampel untuk pengembangan tebal, dan 6 sampel untuk keteguhan lentur serta modulus elastisitas. Teknik analisis data dengan menggunakan uji $t$, yang sebelumnya dilakukan uji analisis persyaratan yaitu normalitas. Bahan yang digunakan dalam penelitian ini adalah partikel eceng gondok dengan ukuran 10 mesh dan perekat urea formaldehida (UF) sebanyak $10 \%$ serta hardener $\left(\mathrm{NH}_{4} \mathrm{CL}\right)$ sebanyak $2 \%$.

Kesimpulan dari penelitian ini yaitu papan partikel eceng gondok 10 mesh dan UF $10 \%$ serta $\mathrm{NH}_{4} \mathrm{CL} 2 \%$ tidak memenuhi standar SNI 032105-2006 dikarenakan sifat mekaniknya di bawah standar SNI 032105-2006.
\end{abstract}

Kata Kunci : papan partikel, eceng gondok

\section{PENDAHULUAN}

Eceng gondok merupakan tanaman pengganggu atau gulma yang pertumbuhannya cepat yang berada di sungai atau saluran air tawar. Untuk mengurangi permasalahan tersebut, maka perlu dilakukan pembersihan sungai atau saluran-saluran air. Supaya eceng gondok ini tidak menumpuk dan menjadi limbah biomassa, maka dapat dilakukan suatu pemanfaatan alternatif terhadap eceng gondok ini dengan jalan pembuatan papan partikel.

\begin{tabular}{|c|c|c|}
\hline $\begin{array}{l}\text { Wahyu Nurramadhan } \\
\text { Alumni Jurusan Teknik Sipil } \\
\text { Fakultas Teknik } \\
\text { Universitas Negeri Jakarta, } 13220\end{array}$ & $\begin{array}{c}\text { Ir. Irza Ahmad, MT } \\
\text { Staff Pengajar Jurusan Teknik Sipil } \\
\text { Fakultas Teknik } \\
\text { Universitas Negeri Jakarta, } 13220\end{array}$ & $\begin{array}{r}\text { Dra. Nira Nasution, M.Pd } \\
\text { Staff Pengajar Jurusan Teknik Sipil } \\
\text { Fakultas Teknik } \\
\text { Universitas Negeri Jakarta, } 13220 \\
\text { email : niranasution@yahoo.co.id }\end{array}$ \\
\hline
\end{tabular}


Eceng gondok diketahui mengandung bahan berligneselulosa dengan kandungan selulosa Cross and Bevan eceng gondok sebesar $64,51 \%$ dari berat total (Joedodibroto 1983, dalam Nuryana 2009), sedangkan pada kayu jati mengandung selulosa 47,5\% (Anonim 1991, dalam lbnu Budi 2006). Kandungan selulosa dan senyawa organik pada eceng gondok berpotensi memberikan nilai kekuatan. Dengan demikian papan partikel dari eceng gondok ini dapat dimanfaatkan sebagai alternatif mengefisienkan penggunaan kayu, disamping itu dapat membuat dampak yang baik pula bagi lingkungan. Di Indonesia sudah banyak yang menghasilkan produk yang terbuat dari eceng gondok seperti produksi tas, sandal, dan kerajinan lainnya. Para peneliti juga sedang mencari manfaat lain yang dihasilkan oleh eceng gondok.

Papan partikel adalah suatu produk kayu yang dihasilkan dari hasil pengempaan panas antara campuran partikel kayu atau bahan berlignesolulosa lainnya dengan suatu perekat organik serta bahan pelengkap lainnya (SNI 03-2105-2006). Maloney (1993) dalam Rofi'ah (2009) mendefinisikan papan partikel sebagai salah satu jenis produk komposit atau panel kayu yang terbuat dari partikel-partikel kayu atau bahan berligneselulosa lainnya, yang diikat dengan kempa panas. Menurut Tsoumis (1991) papan partikel merupakan produk panel yang dibuat dengan proses pereketan partikel, diproduksi dengan ketebalan 0,02 - 4cm.

Berdasarkan kerapatannya FAO (1966), dalam Rofi'ah (2009) mengklasifikasikan papan partikel menjadi tiga golong45an, yaitu:

1. Papan partikel berkerapatan rendah (Low Density Particleboard), yaitu papan partikel yang mempunyai kerapatan kurang dari $0,4 \mathrm{gr} / \mathrm{cm}^{3}$.

2. Papan partikel berkerapatan sedang (Medium Density Particleboard), yaitu papan partikel yang mempunyai kerapatan $0,4-0,8 \mathrm{gr} / \mathrm{cm}^{3}$.

3. Papan partikel berkerapatan tinggi (High Density Particleboard), yaitu papan partikel yang mempunyai kerapatan lebih dari $0,4 \mathrm{gr} / \mathrm{cm}^{3}$.

Eceng gondok dengan bahasa latin Eichornia crassipes, dikenal juga bernama kembang bopong di daerah Jawa, dan bernama kelipuk di daerah Palembang merupakan tumbuhan air yang tumbuh di rawa-rawa, danau, waduk, dan sungai yang alirannya tenang. Tumbuhan ini tumbuh baik pada intensitas cahaya tinggi. Persebaran secara geografi di katulistiwa sampai

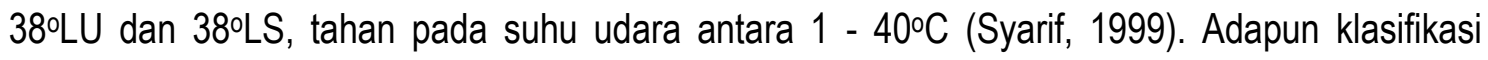
eceng gondok dapat di lihat pada Tabel 1. 
Tabel 1. Klasifikasi Eceng Gondok

\begin{tabular}{|l|l|}
\hline \multicolumn{1}{|c|}{ Kelompok } & \multicolumn{1}{c|}{ Klasifikasi } \\
\hline Kingdom & Embryophytasi phonogama \\
\hline Filum & Magnoliophyta \\
\hline Kelas & Liliopsida \\
\hline Ordo & Liliales \\
\hline Famili & Pontederiaceae \\
\hline Genus & Eichornia \\
\hline Spesies & Eichornia crassipes \\
\hline
\end{tabular}

Sumber: Riz dan Pav (1991), dalam Nuryana (2009).

Kandungan bahan eceng gondok bervariasi seperti kandungan protein 7,4 - 18,1\% dari berat kering. Konsentrasi bahan dasar eceng gondok sama dengan makanan ternak yang tumbuh di darat sedangkan besi, sodium, kalium, dan kalsium relatif tinggi. Pada $100 \mathrm{gr}$ berat kering mengandung Fe 0,3gr, Na 0,4gr, K 4,6gr, Ca 1,3gr, N dan P konsentrasinya sama baik dengan logam berat yang berada langsung di dalam air (Syarif, 1999). Adapun susunan kimia eceng gondok dan pembandingnya kayu jati dalam kering oven dapat dilihat pada Tabel 2.

Tabel 2. Susunan Kimia Eceng Gondok dan Kayu Jati (\% kering oven)

\begin{tabular}{|c|l|c|c|}
\hline No. & \multicolumn{1}{|c|}{ Analisa Komponen } & $\begin{array}{c}\text { Eceng Gondok } \\
(\%)\end{array}$ & $\begin{array}{c}\text { Kayu Jati } \\
(\%)\end{array}$ \\
\hline 1 & Abu & 12,0 & 1,4 \\
\hline 2 & Silikat & 5,56 & 0,4 \\
\hline 3 & Lignin & 7,69 & 29,9 \\
\hline 4 & Pentosan & 15,6 & 14,4 \\
\hline 5 & Selulosa & 64,5 & 47,5 \\
\hline
\end{tabular}

Sumber : 1. Joedodibroto (1983), dalam Nuryana (2009)

2. Anonim 1991, dalam Ibnu Budi (2006)

Urea formaldehida cair adalah perekat kayu hasil reaksi antara urea dan formaldehida (SNI 06-4565-1998). Menurut Hartomo et al. (1992), resin termoset sintetik ini terdapat sebagai sistem dua bagian, terdiri atas resin dan zat pengeras (cairan atau bubuk). Proses settingnya polimerisasi kondensasi dengan eliminasi air. Perekat ini kalah dibandingkan sistem melamin, fenolik atau resorkinol, tidak baik untuk kondisi ekstrim, amat lembab, suhu diatas $60^{\circ} \mathrm{C}$. Menurut Meiwati (2005), harganya relatif murah, tidak berbau, waktu pengerasannya pendek, 
tidak memberikan warna pada produk, dan tahan terhadap air dingin, cukup tahan terhadap air panas tapi tidak tahan terhadap air mendidih.

Hardener sebagai bahan tambah yang berfungsi sebagai pengeras dalam penelitian ini menggunakan $\mathrm{NH}_{4} \mathrm{CL}$ semacam serbuk berwarna putih. Di larutkan pada perekat agar perekat cepat mengeras.

\section{METODA}

Tujuan penelitian ini adalah untuk mengetahui apakah papan partikel dengan bahan baku eceng gondok dapat memenuhi nilai keteguhan lentur, modulus elastisitas lentur, kerapatan, kadar air, dan pengembangan tebal papan partikel sesuai SNI 03-2105-2006.

Penelitian ini dilaksanakan di Laboratorium Biokomposit, Laboratorium Rekayasa dan Desain Bangunan Kayu, dan Laboratorium Peningkatan Mutu, Departemen Hasil Hutan, Fakultas Kehutanan Institut Pertanian Bogor. Waktu penelitian akan dilakukan pada bulan Januari tahun 2011 sampai dengan Februari tahun 2011.

Metode penelitian yang digunakan adalah metode eksperimen di laboratorium dengan benda uji papan partikel yang menggunakan eceng gondok sebagai bahan bakunya. Dalam penelitian ini melibatkan dua variabel yang terdiri dari :

Variabel Bebas $(\mathrm{x}) \quad$ : Eceng gondok sebagai bahan baku papan partikel.

Variabel Terikat (y) : Kerapatan, kadar air, pengembangan tebal, keteguhan lentur, dan modulus elastisitas lentur papan partikel SNI 03-2105-2006.

Dengan kata lain penelitian ini ingin mengetahui seberapa besar mutu papan partikel yang terbuat dari bahan eceng gondok.

Populasi dalam penelitian ini adalah benda uji papan partikel yang terbuat dari eceng gondok dengan ukuran $30 \times 30 \times 1 \mathrm{~cm}$ sebanyak 7 papan..Sedangkan sesuai dengan jenis bahan pengisi yang dipakai untuk papan partikel, maka sampel penelitian yang digunakan adalah eceng gondok yang sudah dijadikan papan partikel. Sampel diambil sebanyak 10 buah dari setiap 1 papan, 1 sampel untuk kerapatan dan kadar air, 3 sampel untuk pengembangan tebal, dan 6 sampel untuk keteguhan lentur dan modulus elastisitas

Bahan yang digunakan adalah eceng gondok yang digunakan dalam penelitian ini adalah eceng gondok kering yang sudah digiling dengan ukuran 10 mesh, perekat yang digunakan pada penelitian ini adalah urea formaldehida (UF) cair dengan kadar 10\%, sedangkan perekat UF yang digunakan dalam penelitian ini diproduksi oleh PT. Pamolite Adhesive Industry (PAI) Probolinggo yang mempunyai resin solid content $49,0 \%-51,0 \%$, dan pengeras (hardener) yang 
digunakan pada penelitian ini adalah memakai Amonium Chlorida $\left(\mathrm{NH}_{4} \mathrm{CL}\right)$ dengan kadar $2 \%$ dari berat resin/ perekat berdasarkan SNI 06-4565-1998.

Alat yang digunakan adalah kempa panas (hot press), oven, cetakan, almunium foil, blender drum, spray gun, timbangan, neraca analitik digital, beacker glass, penggaris, gunting, mikrometerskrup, jangka sorong, desikator, dan spidol.

Proses pembuatan papan partikel dilakukan dengan tahapan-tahapan sebagai berikut:

a. Pembuatan partikel

Batang tanaman eceng gondok dicuci, lalu dikeringkan matahari selama \pm 15 hari. Kemudian setelah kering, di potong $1-1,5 \mathrm{~cm}$ lalu masukan ke mesin penggiling yang dimana mesin penggiling itu di dalamnya terdapat saringan dengan ukuran sesuai yang di inginkan. Dalam penelitian ini menggunakan saringan ukuran 10 mesh.

b. Pengeringan

Partikel eceng gondok dikeringkan di dalam oven hingga kadar air mencapai 2-8 \%.

c. Pencampuran perekat

Partikel yang sudah dikeringkan lalu dimasukan ke dalam mesin pengaduk (blender drum) dan perekat UF (urea formaldehida) dengan Hardener $\left(\mathrm{NH}_{4} \mathrm{CL}\right)$ dimasukkan ke dalam spray gun. Hidupkan blender drum dan semprotkan perekat terhadap pertikel serat eceng gondok tersebut.

d. Pembuatan lembaran

Pada pembuatan lembaran, partikel yang sudah tercampur merata dengan perekat dimasukan ke dalam alat pencetak dengan ukuran $30 \times 30 \mathrm{~cm}$ yang telah dilapisi almunium foil, pada alas cetakan di letakan spacer dengan ketebalan $1 \mathrm{~cm}$. Kemudian cetakan ditutup dengan tutup cetakan yang telah dilapisi almunium foil dan letakan pada alat kempa. Hidupkan alat kempa dan dilakukan pengempaan selama 15 menit dengan panas pada suhu $110^{\circ} \mathrm{C}$ dan tekanan $25 \mathrm{~kg} / \mathrm{cm}^{2}$. Setelah pengempaan selesai, diamkan selama 20 menit agar lembaran papan menjadi dingin. Selanjutnya papan partikel dilepas dari almunium foil dan dikondisikan selama 7 hari. Papan partikel yang sudah dikondisikan selama 7 hari dipotong dan dihaluskan. Pemotongan dan penghalusan ini dilakukan untuk merapihkan bentuk dari papan partikel ini. Untuk lebih jelasnya berikut ini skema proses pembuatan papan partikel yang terdapat pada Gambar 1. 


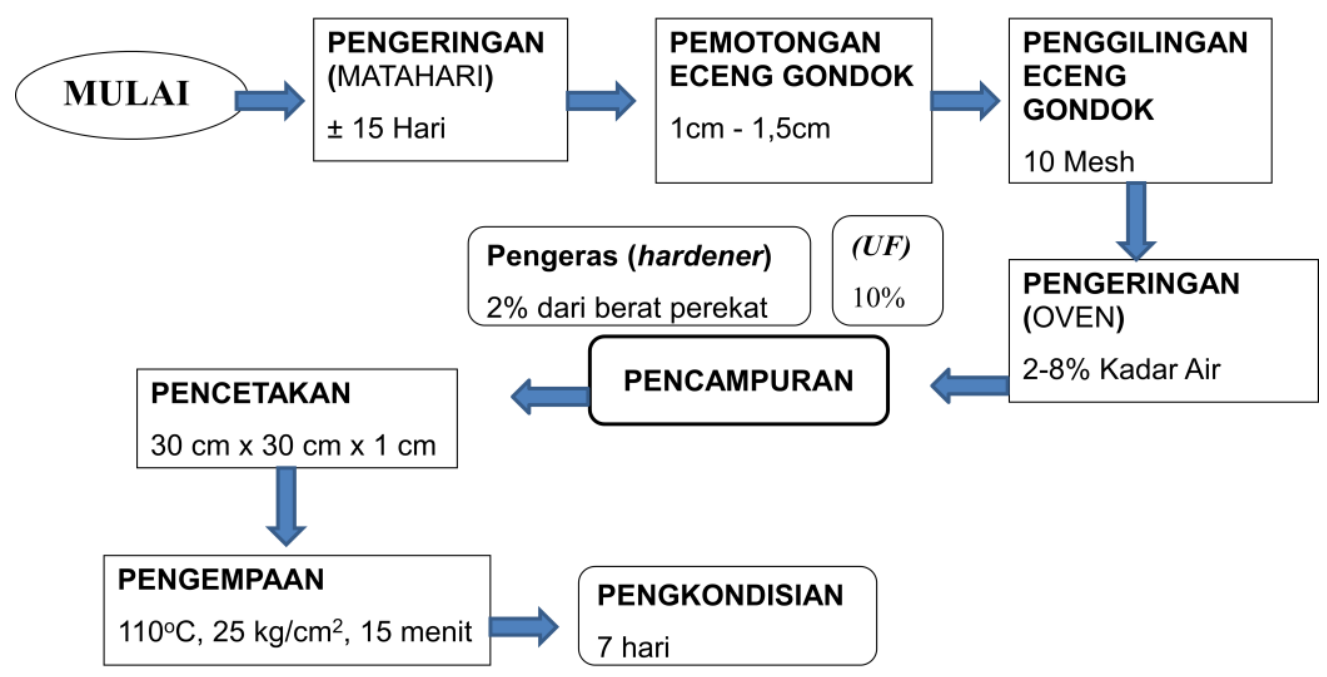

Gambar 1. Skema proses pembuatan papan partikel

\section{PEMBAHASAN HASIL PENELITIAN}

Keteguhan lentur papan partikel eceng gondok 10 mesh dan UF sebanyak $10 \%$ yang diuji menghasilkan nilai keteguhan lentur rata-rata $50,66 \mathrm{~kg} / \mathrm{cm}^{2}$ lebih kecil dari nilai minimum keteguhan lentur berdasarkan SNI 03-2105-2006 yaitu $82 \mathrm{~kg} / \mathrm{cm}^{2}$, sehingga nilai keteguhan lentur papan partikel eceng gondok 10 mesh dan UF sebanyak 10\% tidak memenuhi nilai keteguhan lentur SNI 03-2105-2006.

Modulus elastisitas lentur papan partikel eceng gondok 10 mesh dan UF sebanyak $10 \%$ yang diuji menghasilkan nilai modulus elastisitas lentur rata-rata $5683,83 \mathrm{~kg} / \mathrm{cm}^{2}$ lebih kecil dari niliai minimum modulus elastisitas lentur berdasarkan SNI 03-2105-2006 yaitu $20.400 \mathrm{~kg} / \mathrm{cm}^{2}$, sehingga nilai modulus elastisitas lentur papan partikel eceng gondok 10 mesh dan UF sebanyak 10\% tidak memenuhi nilai modulus elastisitas lentur SNI 03-21052006.

Kerapatan papan partikel eceng gondok 10 mesh dan UF sebanyak 10\% yang diuji menghasilkan nilai kerapatan rata-rata $0,85 \mathrm{~g} / \mathrm{cm}^{3}$ berada pada batas nilai kerapatan berdasarkan SNI 03-2105-2006 yaitu 0,4-0,9 g/ $\mathrm{cm}^{3}$, sehingga nilai kerapatan papan partikel eceng gondok 10 mesh dan UF sebanyak 10\% memenuhi nilai kerapatan SNI 03-2105-2006.

Kadar air papan partikel eceng gondok 10 mesh dan UF sebanyak 10\% yang diuji menghasilkan nilai kadar air rata-rata 13,94\% lebih kecil dari nilai maksimum standar SNI 032105-2006 yaitu 14\%, sehingga nilai kadar air papan partikel eceng gondok 10 mesh dan UF sebanyak 10\% memenuhi nilai kadar air SNI 03-2105-2006. 
Pengembangan tebal papan partikel eceng gondok 10 mesh dan UF sebanyak $10 \%$ yang diuji menghasilkan nilai pengembangan tebal rata-rata $21,3 \%$ lebih besar dari nilai maksimum pengembangan tebal berdasarkan SNI 03-2105-2006 yaitu 12\%, sehingga nilai pengembangan tebal papan partikel eceng gondok 10 mesh dan UF sebanyak 10\% tidak memenuhi nilai kerapatan SNI 03-2105-2006.

\section{KESIMPULAN}

Berdasarkan hasil penelitian yang dilaksanakan sesuai dengan ketentuan SNI 03-2105-2006, hasil yang dapat disimpulkan dari hipotesis yang telah diuji adalah sebagai berikut:

1. Sifat fisik papan partikel eceng gondok 10 mesh dan UF $10 \%$ ditinjau dari pengujian kerapatan memenuhi nilai kerapatan papan partikel SNI 03-2105-2006 yaitu 0,4$0,9 \mathrm{gr} / \mathrm{cm}^{3}$.

2. Sifat fisik papan partikel eceng gondok 10 mesh dan UF $10 \%$ ditinjau dari pengujian kadar air memenuhi nilai kadar air papan partikel SNI 03-2105-2006 yaitu $14 \%$. Pada kadar air terdapat jarak interval yang jauh disebabkan karena pada saat pengovenan tidak kering merata.

3. Sifat fisik papan partikel eceng gondok 10 mesh dan UF $10 \%$ ditinjau dari pengujian pengembangan tebal tidak memenuhi nilai pengembangan tebal papan partikel SNI 03$2105-2006$ yaitu $12 \%$.

4. Sifat mekanik papan partikel eceng gondok 10 mesh dan UF $10 \%$ ditinjau dari pengujian keteguhan lentur tidak memenuhi nilai keteguhan lentur papan partikel SNI 03-21052006 yaitu $82 \mathrm{~kg} / \mathrm{cm}^{2}$. Pada keteguhan lentur terdapat jarak interval yang jauh disebabkan partikel eceng gondok kering cepat meresap kadar air perekat sehingga terjadi penggumpalan didaerah tertentu yang menyebabkan perekat tidak merata.

5. Sifat mekanik papan partikel eceng gondok 10 mesh dan UF $10 \%$ ditinjau dari pengujian modulus elastisitas lentur tidak memenuhi nilai modulus elastisitas lentur papan partikel SNI 03-2105-2006 yaitu $20.400 \mathrm{~kg} / \mathrm{cm}^{2}$.

6. Keseluruhan kesimpulan penelitian yang direncanakan yaitu papan partikel eceng gondok 10 mesh dan UF $10 \%$ serta $\mathrm{NH}_{4} \mathrm{CL} 2 \%$ tidak memenuhi standar SNI 03-21052006 dikarenakan sifat mekaniknya di bawah standar SNI 03-2105-2006. 


\section{DAFTAR PUSTAKA}

Hartomo A. J, Rusdiharsono A, Hardjanto D. Memahami Polimer dan Perekat. Yogyakarta : ANDI OFFSET.

Heyne, K. 1987. Tumbuhan Berguna Indonesia Jilid I. Ed ke-1. Bogor: Badan Penelitian dan Pengembangan Kehutanan, Departemen Kehutanan.

Ibnu Budi Setyawan, Muh. 2006. Pengaruh Penambahan Serbuk Gergaji Kayu Jati Pada Mortar Semen Ditinjau dari Kuat Tekan, Kuat Tarik, dan Daya Serap. [Skripsi]. Semarang : Fakultas Teknik, Jurusan Teknik Sipil, Universitas Negeri Semarang.

Istiany A, Nasution N, Amalia R. 2009. Buku Pedoman Skripsi / Komprehensif / Karya Inovatif (S1). Ja karta: Fakultas Teknik, Universitas Negeri Jakarta.

Meiwati P., Nila. 2005. Pemanfaatan Tandan Kosong Kelapa Sawit Sebagai bahan Baku Papan Partikel Terhadap Mutu Papan Partikel. [Skripsi]. Jakarta : Jurusan Teknik Sipil, Fakultas Teknik, Universitas Negeri Jakarta.

Manullang, Barita Oloan. 1978. Eceng Gondok. Suara Alam vol.1:12-14.

Nuryana, Fahmi. 2009. Pemanfaatan Eceng Gondok (Eichornia crassipes) untuk Bahan Baku Brilet sebagai Bahan Bakar Alternatif. [Skripsi]. Bogor : Fakultas Kehutanan, IPB.

Pasaribu G, Sahwalita. 2006. Pengolahan Eceng Gondok Sebagai Bahan Baku Kertas Seni. Balai Litbang Kehutanan Sumatera: 111-118.

Purboputro, Pramuko I. 2006. Pengaruh Panjang Serat Terhadap Kekuatan Impak Komposit Eceng Gondok Dengan Matriks Poliester. Media Mesin 7(2):70-76.

Rofi'ah Putri, Devina. 2009. Pengaruh Ukuran Contoh Uji Terhadap Beberapa Sifat Papan Partikel dan Papan Serat. [Skripsi]. Bogor : Fakultas Kehutanan, IPB.

Saiman. 1997. Studi Pemanfaatan Ampas Tebu Sebagai Bahan Baku Papan Partikel Dalam Kaitannya Dengan Kekuatan Lentur Standar. [Skripsi]. Jakarta : Jurusan Pendidikan Teknik Bangunan FPTK IKIP Jakarta.

Standar Nasional Indonesia. 1996. Mutu Papan Partikel SNI 03-2105-1996. Jakarta: Badan Standardisasi Nasional.

Standar Nasional Indonesia. 1998. Urea Formaldehida Cair Untuk Perekat Papan Partikel SNI 06-4565-1998. Jakarta: Badan Standardisasi Nasional.

Standar Nasional Indonesia. 2006. Mutu Papan Partikel SNI 03-2105-2006. Jakarta: Badan Standardisasi Nasional.

Sutigno, P. 2006. Mutu Papan Partikel [terhubung berkala]

http://www.dephut.go.id/Halaman/STANDARDISASI_\&_LINGKUNGAN_KEHUTANAN/INFO_VI02/ IV_VI02.htm [23 Oktober 2010] 
Syarif, Fauzia. 1999. Eceng Gondok. Lembaran Informasi PROSEA 2(10):63-65.

Tsoumis, George. 1991. Science and Technologi Of Wood. New York: Van Nostrand Reinhold.

Wikipedia. 2010. Eceng Gondok. [terhubung berkala] http://id.wikipedia.org/wiki/Eceng_gondok [17 November 2010].

Wiryomartono, Suwarno. 1976. Konstruksi Kayu Jilid I. Fakultas Teknik Universitas Gajah Mada, Yogyakarta. 